\title{
ANTIMICROBIAL ACTIVITY OF SELECTED INDIAN FOLK MEDICINAL PLANTS: MYRISTICA FATUA, ALSTONIA BOONEI, HELICTERES ISORA, VITEX ALTISSIMA, AND ATALANTIA RACEMOSA
}

\author{
KOKKAIAH IRULANDI, SETHUPANDIAN GEETHA, PALANICHAMY MEHALINGAM*
}

Department of Botany, V.H.N. Senthikumara Nadar College, Virudhunagar, Tamil Nadu, India. Email: mehalingamp@yahoo.co.in Received: 07 October 2016, Revised and Accepted: 25 October 2016

\section{ABSTRACT}

Objective: To determine antimicrobial activity of methanol, ethyl acetate, and acetone extracts (AEs) of Myristica fatua, Alstonia boonei, Helicteres isora, Vitex altissima, and Atalantia racemosa against different species of pathogens, Streptococcus faecalis, Escherichia coli, Klebsiella pneumoniae, Pseudomonas aeruginosa, Bacillus subtilis, Staphylococcus aureus, and Candida albicans.

Methods: Antimicrobial activity of various plant extracts was measured by agar well diffusion method.

Results: AE of A. boonei showed the highest inhibitory effect against $E$. coli $(20.83 \pm 0.32 \mathrm{~mm})$ and $S$. faecalis $(19.00 \pm 1.00 \mathrm{~mm})$. All the extracts of $H$. isora leaves showed different zone of inhibition observed in all the tested pathogens ranges between $8.13 \pm 1.53$ and $15.25 \pm 1.23 \mathrm{~mm}$. Ethyl acetate extract of $V$. altissima showed highest activity against $B$. subtilis $(19.67 \pm 1.53 \mathrm{~mm})$. Methanol and acetone leaves extracts of $A$. racemosa have good fungal activity against the $C$. albicans $(19.33 \pm 1.26-16.00 \pm 1.00 \mathrm{~mm})$. Methanol extract of $M$. fatua showed high antimicrobial activity against $P$. aeruginosa $(15.10 \pm 0.17 \mathrm{~mm})$ and B. subtilis $(14.23 \pm 0.21 \mathrm{~mm})$.

Conclusion: The results from the study suggest that the leaves of M. fatua, A. boonei, H. isora, V. altissima, and A. racemosa showed good antimicrobial activity against the different pathogens. They are used as the alternative source for the control and treatment of microbial infections.

Keywords: Antimicrobial activity, Leaves extracts, Well diffusion method, Pathogenic strains.

(c) 2017 The Authors. Published by Innovare Academic Sciences Pvt Ltd. This is an open access article under the CC BY license (http://creativecommons. org/licenses/by/4. 0/) DOI: http://dx.doi.org/10.22159/ajpcr.2017.v10i2.15572

\section{INTRODUCTION}

The use of medicinal plants is a very important therapeutic resource for the treatment of diseases and the use of traditional medicine has expanded globally and is gaining popularity. It has continued to be used not only for primary health care of the in developing countries [1]. The most important of these bioactive compounds are flavonoids, stilbenes, and alkaloids are used antimicrobial activity [2].

Vitex altissima L.f. (Syn.: Vitex appendiculata Rottler.; Vitex zeylanica Turcz., nom. illeg.) belongs to the family Lamiaceae which includes approximately 3500 species in 220 genera, distributed worldwide, but mostly in the Mediterranean region and South West Asia. The largest gener are (Salvia 900), (Scutellaria 360), (Stachys 300), (Teucrium 250), and Vitex 250), it is also used in stomatitis, cardiac diseases, anorexia, blindness, leprosy, worm infestation, rheumatic swellings, and chest pain [3]. It also has anti-inflammatory (Sridhar et al., 2004) and antioxidant properties [4].

The plant Atalantia racemosa Wight, belonging to the family Rutaceae is commonly called as Kattu naragam in Tamil. It is widely distributed Peninsular India, and Western Ghats - South, Central, and south Maharashtra Sahyadris. A. racemosa leaves decotion is used in the treatment of bronchitis, asthma and cough, bronchi and blood purifier [5]. The plant $A$. racemosa is routinely used by tribes around Tamil Nadu to alleviate various diseases [6-8]. In this plant identified important bioactives are campesterol and stigmasterol from fruit extract [9].

Helicteres isora $\mathrm{L}$. is belongs to family Sterculiacae is a sub-deciduous shrub. The species is native to Asia and Australia [10]. It occurs, throughout India, from Jamuna eastwards to Nepal, Bihar and Bengal and southern India and Andaman Islands. The fruits of $H$. isora is commonly used to the astringent, acrid, refrigerant, demulcent, constipating, stomachic, vermifuge, vulnerary, hemostatic and urinary astringent. Colic, flatulence, diarrhea, dysentery, verminosis, wounds, ulcers, hemorrhages, epistaxis and diabetes [11]. In this plant shows number of bioactive compounds such as saponins, tannins, anthraquinones, alkaloids, triterpens, flavanoids, glycosides, reduced sugar, and phlobatannins [12].

Alstonia boonei De Wild. belongs to the family Apocynaceae. It is important medicinal plant used in various purposes to antiinflammatory, analgesic, and antipyretic activities in Africa [13]. The crucial medicinal plants of genus Alstonia includes Alstonia scholaris, Alstonia congensis, and Alstonia macrophylla which have proved to be useful in various diseases by different parts of this plants and it is distributed throughout the tropical and the rain forest of west and Central Africa (Olever-Bever, 1986) [13-15]. A. boonei shows medicinal effective phytoconstituents are alkaloids and tannins [16].

Myristica fatua Houtt. is commonly known as Kottapannu is belongs to the family Myristicaceae. It is fresh water swampy evergreen forests grow up to $600 \mathrm{~m}$. It is distributed in Southern Western Ghats and Endemic to the Western Ghats - Agasthyamalai (West) and Central Malanad. In this plant, commonly used to the antimycobacterial and antiparasitics [17].

This paper mainly focused on the antimicrobial activity of five different medicinal plants against selected bacteria and fungus. These medicinal plants are used in various folk medicines by the local communities in India. 


\section{METHODS}

\section{Collection of plant material}

The fresh plants were collected from Sadhuragiri hills, Virudhunagar District, Tamil Nadu, and India. Taxonomic identification of the plants was carried out with the help of Dr. R. Ramasubbu, Assistant Professor, Ganghigram Rural Institute - Deemed University, Gandhigram, Tamil Nadu, India.

\section{Preparation of leaves extracts}

The dried leaves extracts were prepared by sequential extraction method using three organic solvents in the basis of the polarity of solvents (acetone, ethyl acetate, and methanol). $30 \mathrm{~g}$ of dried leaf powder sample was taken in a conical flask and $200 \mathrm{ml}$ of acetone was added. The conical flask was kept on mechanical shaker for $24 \mathrm{hrs,}$ after that the extract was filtered through Whatman filter paper 1 and the pellet was allowed for drying and this pellet was used for the next solvent extraction (ethyl acetate and methanol). The dried extract was recovered and stored in refrigerator for further analysis.

\section{Extract recovery percentage}

After drying the respective extracts under oven temperature at $40^{\circ} \mathrm{C}$, the percentage of extracts yield was calculated using the following equation.

$$
\% \text { Yield }=\frac{\text { Extract }+ \text { container }(\mathrm{g})-\text { Empty container }(\mathrm{g})}{\text { Sample weight }(\mathrm{g})} \times 100
$$

\section{Antimicrobial activity}

Staphyllococcus aureus, Streptococcus faecalis, Bacillus subtilis, Escherichia coli, Pseudomonas aeruginosa, Klebsiella pneumoniae, and fungus Candida albicans. All samples were procured from Department of Biology, Gandhigram Rural Institute - Deemed University, Gandhigram.

The test organisms were maintained on nutrient agar slant and kept in a refrigerator at $4^{\circ} \mathrm{C} .100 \mathrm{ml}$ aliquots of nutrient broth were inoculated with the culture of test microorganisms using a loop and then incubated at $37^{\circ} \mathrm{C}$ for $24 \mathrm{hrs}$

Antimicrobial activities of methanol, ethyl acetate, and acetone fractions of plants were carried out using the agar well-diffusion method. MuellerHinton agar medium (MHA) was used for antimicrobial susceptibility tests. The MHA medium was prepared by pouring $20 \mathrm{ml}$ of molten media into sterile Petri plates. The plates were allowed to solidify, and $0.2 \mathrm{ml}$ of an overnight broth culture of test microorganisms was added to $20 \mathrm{ml}$ of cooled molten agar on the medium and allowed to dry for 5 minutes. For agar well diffusion method, four equidistant wells ( $6 \mathrm{~mm}$ in diameter) were cut from the agar with the help of a cork-borer. $40 \mu \mathrm{l}$ of leaves extracts (methanol, ethyl acetate, and acetone extracts [AEs]) containing (4 mg) concentration was loaded on $6 \mathrm{~mm}$ well. The standard antibiotic solution gentamicin $(10 \mu \mathrm{g})$ was placed on the surface of the plates. The plates were kept for incubation for $24 \mathrm{hrs}$ at $37^{\circ} \mathrm{C}$. The zone of inhibition was measured around the well-containing samples and standard. The experiments were performed in triplicates.

\section{Statistical analysis}

All the data were reported as mean \pm standard deviation of three replicates. Statistical analysis was performed using Microsoft Excel.

\section{RESULTS}

\section{Extract recovery percentage}

The extractive values of five different plants in different solvent extracts are given in Table 1. The highest extractive yield was found in the A. boonei in methanol extract (ME) and followed ethyl acetate and AE.

\section{Antimicrobial activity}

A. boonei

Antimicrobial activity of $A$. boonei all tested extracts were activity screened against all tested microorganisms. The results of the zone of inhibition are summarized in Fig. 1. The AEs showed the inhibitory effect against $E$. coli $(21.00 \pm 1.00 \mathrm{~mm})$ and $S$. faecalis $(19.00 \pm 1.00 \mathrm{~mm})$, with compared to positive control. ME shows maximal inhibitory effect against all the test organisms. Ethyl acetate extract (EAE) of A. boonei showed significant antimicrobial activity against $B$. subtilis $(17.67 \pm 0.47 \mathrm{~mm})$. ME of $A$. boonei leaf showed similar inhibition zones were observed against $K$. pneumoniae and $P$. aeruginosa $(13.67 \pm 0.47 \mathrm{~mm})$. As a result of this plant, extract has high effect of antimicrobial activity.

\section{A. racemosa}

Antimicrobial activity of different leaf extract of A. racemosa was assayed against various bacterial and fungal pathogens by agar well diffusion method showed in Fig. 2. The result revealed that all the extracts were found to be significant against all the bacterial and fungal pathogens. It was observed that all the three solvent extracts showed prominent antimicrobial activity between $9.50 \pm 0.29$ and $20.67 \pm 0.76 \mathrm{~mm}$ against most of the microorganisms used in the study. The ME of $A$. racemosa showed maximum antimicrobial potential followed by acetone and EAE. The ME of A. racemosa was most sensitive against $K$. pneumonia $(20.67 \pm 0.76 \mathrm{~mm})$, and least activity was observed against $S$. aureus and P. aeruginosa $(9.67 \pm 0.76 \mathrm{~mm})$. AE was more effective against $C$. albicans $(16.00 \pm 1.00 \mathrm{~mm})$ than compared to other studied cultures. The EAE of $A$. racemosa showed exhibited zone of inhibition against $E$. coli $(12.50 \pm 0.29 \mathrm{~mm})$ followed by $S$. faecalis $(11.50 \pm 0.29 \mathrm{~mm}), B$. subtilis and C. albicans $(11.33 \pm 0.63 \mathrm{~mm}), K$. pneumoniae and P. aeruginosa $(10.67 \pm 0.54 \mathrm{~mm})$, and $S$. aureus $(9.50 \pm 0.29 \mathrm{~mm})$.

\section{H. isora}

Different solvent extracts of $H$. isora showed significant antimicrobial activity against all the seven microbial strains in Fig. 3. The AE demonstrated the highestactivity followed by the methanol and EAE. The EAE showed the highest activity against $S$. faecalis $(14.00 \pm 0.00 \mathrm{~mm})$ and minimal activity against $K$. pneumoniae $(8.13 \pm 0.23 \mathrm{~mm})$. A significant growth inhibition was observed AE against $S$. faecalis $(17.00 \pm 0.00 \mathrm{~mm})$,

Table 1: Extractive value of plant extracts

\begin{tabular}{llll}
\hline Plants & ME $(\% \mathbf{w} / \mathbf{w})$ & EAE $(\% \mathbf{w} / \mathbf{w})$ & AE $(\% \mathbf{w} / \mathbf{w})$ \\
\hline A. boonei & 11.33 & 9.66 & 8.06 \\
A. racemosa & 8.44 & 2.66 & 5.75 \\
H. isora & 10.03 & 7.75 & 4.96 \\
M. fatua & 6.03 & 4.16 & 2.66 \\
V. altissima & 9.33 & 8 & 2.83 \\
\hline
\end{tabular}

A. boonei: Alstonia boonei, A. racemosa: Atalantia racemosa, H. isora: Helicteres isora, M. fatua: Myristica fatua, V. altissima: Vitex altissima, ME: Methanol extract, EAE: Ethyl acetate extract, AE: Acetone extract

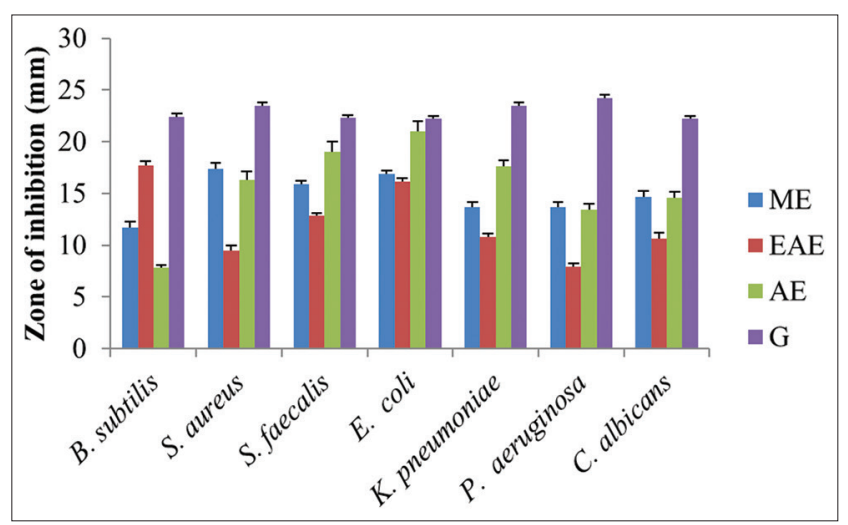

Fig. 1: Antimicrobial activity of Alstonia boonei leaf extracts. Each value represents mean \pm standard deviation of three replicates. ME - Methanol extract, EAE - Ethyl acetate extract, AE - Acetone extract, G - Gentamicin, plant extracts - $4 \mathrm{mg}$ ( 0 - No inhibition) 


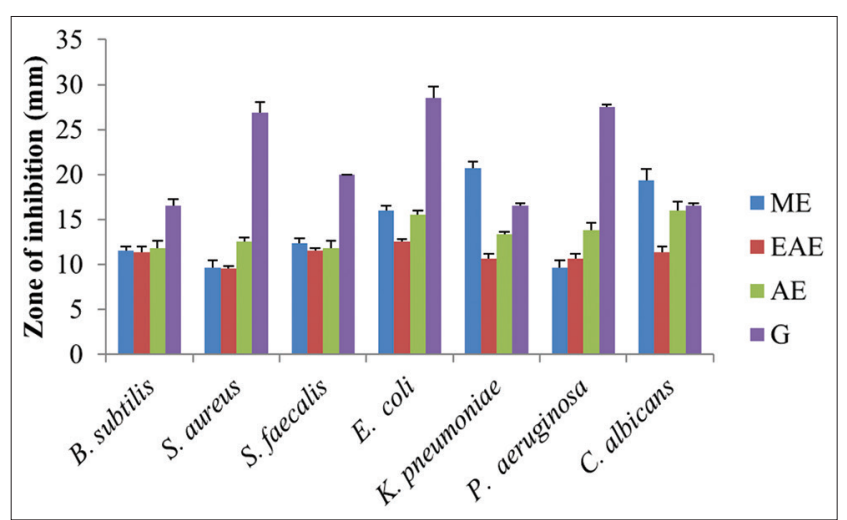

Fig. 2: Antimicrobial activity of Atalantia racemosa leaf extracts. Each value represents mean \pm standard deviation of three replicates. ME - Methanol extract, EAE - Ethyl acetate extract, AE - Acetone extract, G - Gentamicin, plant extracts - 4 mg (0 - No inhibition)

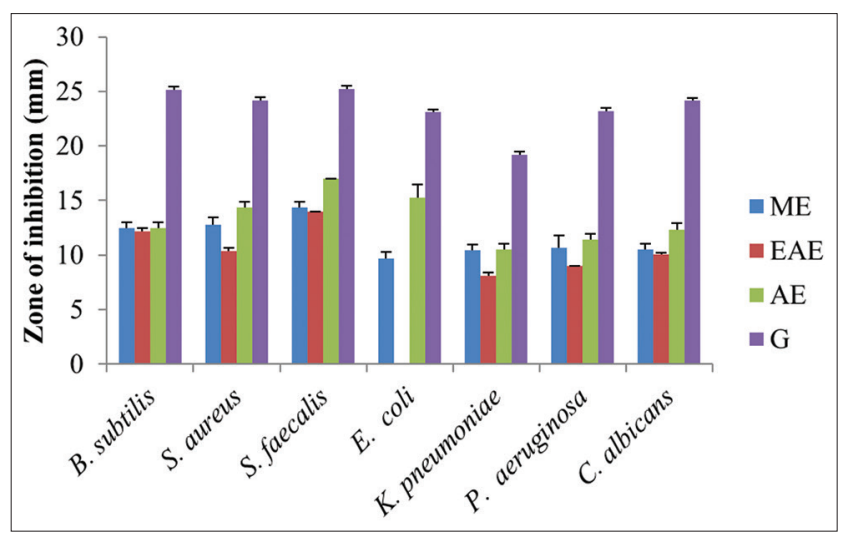

Fig. 3: Antimicrobial activity of Helicteres isora leaf extracts. Each value represents mean \pm standard deviation of three replicates. ME - Methanol extract, EAE - Ethyl acetate extract, AE - Acetone extract, G - Gentamicin, plant extracts - 4 mg (0 - No inhibition)

E. coli $(15.25 \pm 1.23 \mathrm{~mm})$ and $S$. aureus $(14.33 \pm 0.58 \mathrm{~mm})$. There is no any activity of EAE against $E$. coli $(0.00 \pm 0.00 \mathrm{~mm})$. They results MEs showed poor response against $E$. coli $(9.67 \pm 0.58 \mathrm{~mm})$.

\section{M. fatua}

M. fatua showed broad spectrum of antimicrobial activity in all tested microorganisms. These results suggest that all the three solvent extracts possess antibacterial and antifungal activity against such as E. coli, P. aeruginosa, S. aureus, B. subtilis, K. pneumoniae, S. faecalis and C. albicans showed in Fig. 4. Different solvent extracts of Myristica fragrans showed significant activity against all the seven microbial strains. The ME exhibited highest activity against $P$. aeruginosa with the diameter of zone of inhibition of $15.10 \pm 0.17 \mathrm{~mm}$ and $B$. subtilis $(14.23 \pm 0.21 \mathrm{~mm})$ respectively, and least activity was noted against $S$. aureus $(8.23 \pm 0.25 \mathrm{~mm})$. AE more potent effect against $P$. aeruginosa $(12.17 \pm 0.29 \mathrm{~mm})$ and least activity against $S$. faecalis $(11.17 \pm 0.29 \mathrm{~mm})$. Similarly, EAE was found to be active with the zone of inhibition against B. subtilis $(9.17 \pm 0.29 \mathrm{~mm})$, K. pneumoniae $(9.00 \pm 0.00 \mathrm{~mm})$, E. coli $(8.00 \pm 0.00 \mathrm{~mm})$ and C. albicans $(8.23 \pm 0.21 \mathrm{~mm})$ and loss of activity against $P$. aeruginosa, $S$. aureus and $S$. faecalis $(0.00 \pm 0.00)$.

\section{V. altissima}

Agar well diffusion method was used to assess the antimicrobial activity against the human affected pathogens by measuring the zone of inhibition ( $\mathrm{mm}$ ). Most of the extracts showed significant antimicrobial activity against the tested organisms at the same concentration of

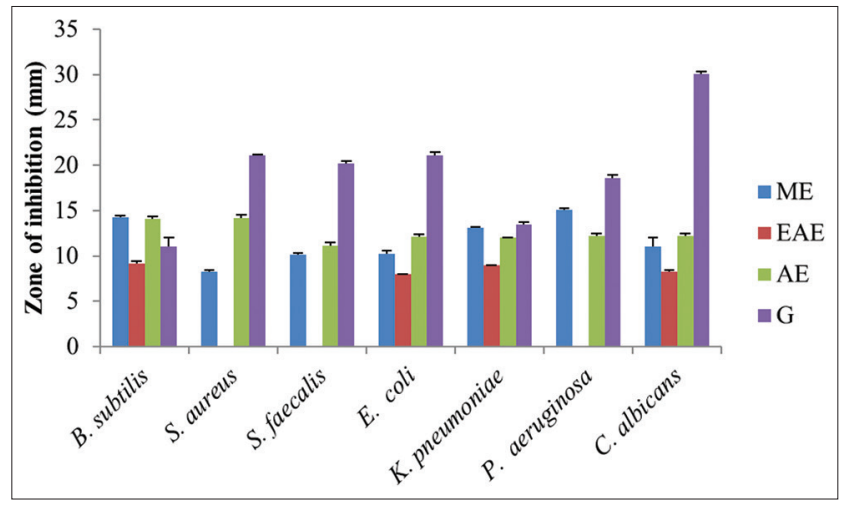

Fig. 4: Antimicrobial activity of Myristica fatua leaf extracts. Each value represents mean \pm standard deviation of three replicates. ME - Methanol extract, EAE - Ethyl acetate extract, AE - Acetone extract, G - Gentamicin, plant extracts - $4 \mathrm{mg}$ (0 - No inhibition)

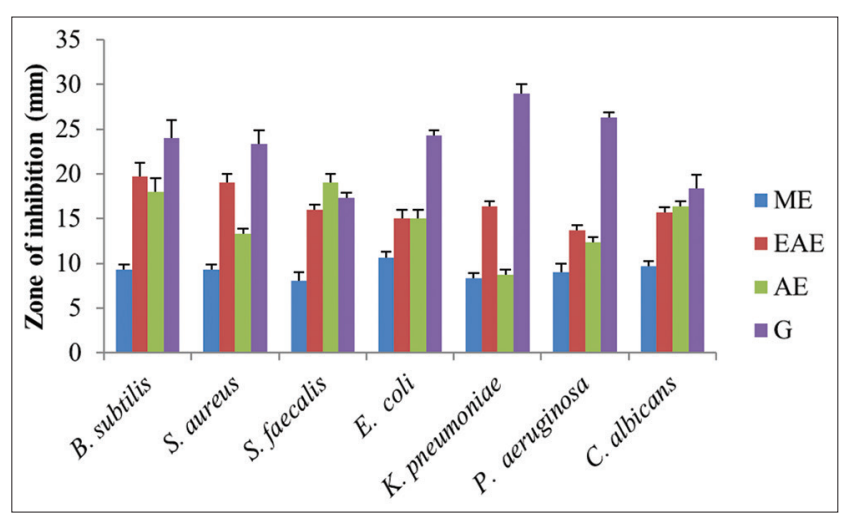

Fig. 5: Antimicrobial activity of Vitex altissima leaf extracts. Each value represents mean \pm standard deviation of three replicates. ME - Methanol extract, EAE - Ethyl acetate extract, AE - Acetone extract, G - Gentamicin, plant extracts - $4 \mathrm{mg}$ (0 - No inhibition)

$4 \mathrm{mg} / \mathrm{ml}$ (Fig. 5). In general, AE demonstrated higher antimicrobial activity than the other solvent extracts. The ethyl acetate leaves extract was the most effective against the tested organisms. It recorded the highest zone of inhibition of $19.67 \pm 1.53 \mathrm{~mm}$ against $B$. subtilis and $19.00 \pm 1.00 \mathrm{~mm}$ against $S$. aureus at $4 \mathrm{mg} / \mathrm{ml}$. This is significant activity compared with the activity of the standard gentamicin which showed zones of inhibition ranges from $17.33 \pm 0.58$ to $29.00 \pm 1.00 \mathrm{~mm}$. The results of antimicrobial activity are given in which clearly show that the EAE of $V$. altissima has both antibacterial and antifungal activity against the tested organisms.

\section{DISCUSSION}

The presence of phytochemicals in the plant extracts highly correlated to the biological activity [18]. From this revealed significant antimicrobial activity possess in the all the studied plant extracts. Nowdays, number researcher evaluated the antimicrobial compounds from plant material, they act as lesser side effect in the human body. The present study corroborates with the antimicrobial activity of various plant extracts against $S$. aureus and E. coli [18]. In earlier researcher reported the ME produce moderate antimicrobial activity against the microbial pathogens [19]. AE of $M$. fragrans seed extract showed antibacterial and antifungal activity against $S$. aureus $(13.8 \pm 0.42 \mathrm{~mm})$ and Aspergillus niger $(14.4 \pm 0.37 \mathrm{~mm})$ with zone of respectively for $10 \mu \mathrm{g} / \mathrm{ml}$ of extract solution [20]. In earlier record showed ethanol root extract of $A$. boonei exhibited inhibition against various pathogens such as $S$. aureus $(8-10 \mathrm{~mm}), B$. subtilis $(6-8 \mathrm{~mm})$, P. aeruginosa $(5-8 \mathrm{~mm})$, E. coli $(5-8 \mathrm{~mm})$ and fungus $C$. albicans $(5-9 \mathrm{~mm})$ with volume of extract solutions ranging from 2.5 to $10 \mathrm{mg} / \mathrm{ml}$ [21]. In previous study reported 
contrary result on MEs of $H$. isora leaf showed antimicrobial activity against $E$. coli $(15.28 \mathrm{~mm})$ and fungus $A$. niger $(11.30 \mathrm{~mm})$ showed good zone of inhibition and concentration was $(10 \mathrm{mg} / \mathrm{ml})[22]$. The present study coincides with the antimicrobial activity of aqueous extracts of V. altissima [23]. Atalantia species showed good antimicrobial activity against the tested pathogens are Atalantia hydrophila followed by Proteus mirabilis, P. aeruginosa, Proteus vulgaris and E. coli while our findings also exhibited the same results against $P$. aeruginosa and E. coli [24]. In this study, showed good zone of inhibition against all the tested pathogens and activities were compared with positive control gentamicin.

\section{CONCLUSION}

The significant inhibitory activity of all the tested extracts $M$. fatua, A. boonei, $H$. isora, $V$. altissima and A. racemosa was noted against different pathogenic microorganisms. These five plant extracts could be studied further as future control the common pathogenic microbes. Phytochemical analysis could be carried out to isolate the bioactive compounds of these plant species, which act as antimicrobial agents.

\section{ACKNOWLEDGMENT}

The authors are grateful to Managing Board of V.H.N. Senthikumara Nadar College (Virudhunagar) for their financial support.

\section{REFERENCES}

1. Freitas PC. Atividade antioxidante de espécies medicinais da família Piperaceae: Pothomorphe umbellata (L) Miq e Piper regnellii (Miq) CDC/Antioxidant activity species medicinals of Piperaceae family: Pothomorphe umbellata (L) Miq and Piper regnellii (Miq) CDC. São Paulo: Fonte; 1999. p. 115.

2. Asase A, Kokubun T, Grayer RJ, Kite G, Simmonds MS, Oteng-Yeboah AA, et al. Chemical constituents and antimicrobial activity of medicinal plants from Ghana: Cassia sieberiana, Haematostaphis barteri, Mitragyna inermis and Pseudocedrela kotschyi. Phytother Res 2008;22:1013-6.

3. Parrotta JA. Healing Plants of Peninsular India. USA: CABI Publishers; 2001. p. 770.

4. Sridhar C, Rao KV, Subburaju GV. Flavonoids, triterpenoids and a lignin from Vitex altissima. Phytochemistry 2005;66:1707-12.

5. Pullaiah T. Encyclopaedia of World Medicinal Plants. New Delhi: Regency Publisher; 2006. p. 2442.

6. Devi Prasad G, Shyma TB, Raghavendra MP. Plants used by the tribes for the treatment of digestive system disorders in Wayanad district, Kerala. J Appl Pharm Sci 2013;3(8):171-5.

7. Arinathan V, Mohan VR, De Britto AJ. Ethnomedicinal survey among Palliyar tribals of Srivilliputhur Grizzled Giant Squirrel Wildlife Sanctuary, Tamil Nadu. J Econ Taxon Bot 2003;27:707-10.

8. Das AK, Stalin N, Muthuperumal C, Swamy PS. Wild plants used by Muthuvan and Kattunaikkan tribal communities of Palakkayam settlement in Nilambur of Malappuram district, Kerala. Med Plants Int J Phytomed Related Ind 2013;5(2):82-9.

9. Das AK, Swamy S. Antioxidant activity and determination of bioactive compounds by GC-MS in fruit methanol extracts - A comparative analysis of three Atalantia species from south India. J Appl Pharm Sci 2016;6(2):130-4

10. Bhattacharjee SK. Handbook of Medicinal Plants. Jaipur: Pointer Publishers; 1998. p. 179-80.

11. Warrier PK, Nambiar VP. Indian Medicinal Plants. Vol. 3. Madras: Orient Longman Ltd.; 1995. p. 132-5.

12. Khandelwal KR. Preliminary phytochemicals screening. Practical Pharmacognosy Techniques and Experiments. $8^{\text {th }}$ ed. Pune: Nirali Publication; 2001. p. 149-56.

13. Adotey JPK, Adukpo GE, Boahen YO, Armah FT. A Review of the Ethnobotany and Pharmacological Importance of Alstonia boonei De Wild (Apocynaceae). ISRN 2012;9.

14. Olever-Bever D. Propagatin and management, functional uses of medicinal plants. In: Medicinal Plant Tropical West Africa. Vol. 2. Cambridge: University Press; 1998. p. 89-90.

15. Olajide OA, Awe SO, Makinde JM, Ekhelar AI, Olusola A, Morebise O, et al. Studies on the anti-inflammatory, antipyretic and analgesic properties of Alstonia boonei stem bark. J Ethnopharmacol 2000;71(1-2):179-86.

16. Afolabi CA, Ibukun EO, Afor E, Akinrinlola BL, Onibon TR, Akinboboy AO, et al. Chemical constituents and antioxidant activity of Alstonia boonei. Afr J Biotechnol 2007;6(10):1197-201.

17. Billo M, Cabalion P, Waikedre J, Fourneau C, Bouttier S, Hocquemiller R, et al. Screening of some new Caledonian and Vanuatu medicinal plants for antimycobacterial activity. J Ethnopharmacol 2005;96(1-2):195-200.

18. Lavanya J, Selvam S, Priya M, Jacintha P, Aradana M. Antioxidant and antimicrobial activity of selected medicinal plants against human oral pathogens. Int J Pharm Pharm Sci 2016;8:9.

19. Irulandi K, Geetha S, Suresh M, Siva V, Nirmalkumar N, Mehalingam P. Antimicrobial and phytochemical analysis of different solvent extracts of barks of Syzygium laetum (Buch.-Ham.) Gandhi. J Nat Prod Plant Resour 2016;6(4):15-9.

20. Ashish AD, Vipin KB, Vikash B, Maithil N. Chemistry, antioxidant and antimicrobial potential of nutmeg (Myristica fragrans Houtt). J Genet Eng Biotechnol 2013;11:25-31.

21. Opoku F, Akoto O. Antimicrobial and phytochemical properties of Alstonia boonei extracts. Org Chem Curr Res 2015;4:137.

22. Sanjeet K, Jana PK, Kumari M, Patnaik N, Nayak AK, Kumar P. Validation of tribal claims through pharmacological studies of Helicteres isora L. leaf extract: An empirical research. Int J Drug Dev Res 2013;5(1):279-85.

23. Dayana GJ, Alphonsa JK, Ramani VA, Xavier TF, Auxilia A. Phytochemical screening and antimicrobial studies on the medicinal plant Vitex altissima L. World J Pharm Pharm Sci 2015;4(9):705-16.

24. Thirugnanasampandan R, Gunasekar R, Gogulramnath M. Chemical composition analysis, antioxidant and antibacterial activity evaluation of essential oil of Atalantia monophylla Correa. Pharmacognosy Res 2015;7 Suppl 1:S52-6. 